\title{
Bonded Labour: The Scenario in the Last Decade of the Last Millennium
}

Ramesh Raj Kunwar*

\section{The Concept}

The age old social status of men and women has not changed with time. As a result, those who were at the status of slavery, serfdom, debt-bondage and free labour have remained the same. Servility and debt- bondage system has been studied by several scholars like Breman ${ }^{1}$, Chanana ${ }^{2}$, Foucault ${ }^{3}$, Genovese ${ }^{4}$, Miers and Kopytoff ${ }^{5}$, Patterson ${ }^{6}$, Davis ${ }^{7}$, Finley ${ }^{8}$ and Watson ${ }^{9}$. In its continuation the history of slavery, serfdom and debt-bondage as progressive steps in the direction towards free labour. Bondage as a general category, whether caused by money or any other object, is the product of the Enlightenment and the post-Enlightenment discourses that discovered humanity and revealed liberty as the essence of humanity ${ }^{10}$.

With the development of commodities comes the process that Marx has labeled as the fetishism of commodities. The fetishism of commodities involves the process by which actors fail to recognize that it is their labour that gives the commodities their value. They fetishize those commodities and come to believe

* Dr. Ramesh Raj Kunwar is an Associate Professor in the Central Department of Nepalese History, Culture and Archaeology (NeHCA), Tribhuvan University, Kirtipur. He is also the Head of the Department of Humanities and Social Sciences, Royal Nepalese Military Academy, Kharipati, Bhaktapur.

1. Jan Breman, Patronage and Exploitation: Emerging Agrarian Relations in South Gujrat, India, Berkeley: University of California Press, 1974.

2. Dev Raj Chanana, Slavery in Ancient India, New Delhi : People's Publishing House, 1960.

3. Michel Foucault, The Archaeology of Knowledge, M.A. Sheridan Smith (tr.), New York : Pantheon, 1972.

4. Eugene D. Genovese, From Rebellion to Revolution : Afro-American Salve Revolts in the Making of the Modern World, Baton Rouge and London: Lousiana State University Press, 1979.

5. Suzanne Miers and Igor Kopytoff, "African 'Slavery' as an Institution to Marginality", in S.Miers and I. Kopytoff(eds.), Introduction to Slavery in Africa : Historical Anthropological Perspectives, Madison : University of Wisconsin Press, 1977.

6. Orlando Patterson, Slavery and Social Death : A Comparative Study, Massachusetts : Harvard University Press, 1982.

7. David Brian Davis, Slavery and Human Progress, New York : Oxford University Press, 1984.

8. Moses Finley, "Economy and Society in Ancient Greece", London : Chatto \& Windus, 1981.

9. J.L.Watson, "Slavery as an Institution : Open and Closed Systems", in James L. Watson (ed.), African and Asian Systems of Slavery, Berkeley : University of California, 1979.

10. Gyan Prakash, Bonded Histories: Geneological of Labour Servitude in Colonial India, Cambridge: Cambridge University Press, 1990. 
that value arises from the natural properties of the things themselves. Thus the market takes on a function in the eyes of the actors that in Marx's view only actors could perform-the production of value. In Marx's terms, "A definite social relation between men...assumes, in their eyes, the fantastic form of a relation between things" ${ }^{11}$. Granting reality to commodities and the market, the individual in capitalism progressively loses control over them.

Looked at in this way, the fetishism of commodities is translated into the concept of reification ${ }^{12}$. Reification can be thought of as "thingification," or the process of coming to believe that humanly created social forms are natural, universal, and absolute things and, as a result, that those social forms do acquire those characteristics. The concept of reification implies that people believe that social structures are beyond their control and unchangeable. By using this concept, we can see that people reify the whole range of social relationships and social structures. Marx argued that, as a social phenomenon, labour becomes a commodity under the peculiar circumstances of capitalism. After all, whereas commodity fetishism was founded on the free exchange of labour power as a commodity, debt-bondage not only implied that social relations were based on money but also that its identity was derived from the opposition it posed to free labour. In this sense, debt-bondage animates an inanimate object like money with a power to bind people, and it naturalizes free labour by positing bondage as the suspension of "natural" rights to freedom ${ }^{13}$.

Patterson $^{14}$ in his sociological analyses of slavery concluded that the struggle against "social death" of the slaves has given birth to the notion of freedom. Miers and Kopytoff ${ }^{15}$ studied on African slavery and concluded slave - kin continuum hold. If in "premodern societies the salient characteristic of slavery was its antithetical relation to the normal network of kinship ties of dependency, protection, obligation, and privilege," then slavery could not have always meant unfreedom, and the struggle against the disabilities that the slaves were subjected to was unlikely to invoke freedom in the same sense at all times and places $^{16}$. Finley ${ }^{17}$ notes, "It was only between classes, between rich and poor, to put it in loose and simple terms, that debt led to bondage in practice" ${ }^{18}$ Breman's seminal work on bonded labour in south Gujarat which escapes the free-unfree

11. Karl Marx, Capital: A Critique of Political Economy, Vol. I, New York : International Publishers, Reprint, 1967, p. 72.

12. George Lukacs, History and Class Consciousness, Cambridge, Massachusetts : MIT Press, Reprint, 1968.

13. Prakash, f.n.no.10.

14. Patterson, f.n.no.6.

15. Miers and Kopytoff, f.n.no.5.

16. Davis, f.n.no.7, pp. 15-16.

17. Finley, f.n.no.8, p. 153.

18. Quoted from Prakash, f.n.no.10. 
conception by situating the labourers and their domination by the landlords in patron-client ties animated by the Hindu caste system ${ }^{19}$.

By making labour power into an exchangeable commodity, capitalism represented slavery as the opposite of that free exchange. In this regard, Genovese $^{20}$ remarks, "The power of slavery as a cultural myth in modern societies derives from its antithetical relationship to the hegemonic ideology of bourgeois social relations of production. "Opposed to free labour and free individuality, slavery became tantamount to the suppression of innate rights, giving rise to what Foucault called the "repressive hypothesis" in his study of sexuality ${ }^{21}$. By this hypothesis, according to Foucault, power presents itself only as a restraining forces, as a thing "that only has the negative on its side, a power to say no; in no condition to produce, capable only of posting limits..."

Watson's "open systems of slavery" and "closed systems of slavery" and Pierre Bourdieu's ${ }^{22}$ "symbolic violence" has also become the theme for the discussion of bonded labour problem.

Prakash $^{23}$ shows that the bonded labour, Kamia, is popular in eastern province of Bihar. As he writes, "... these labourers were distinguished by long-term ties to landlords known as maliks. A Kamia worked all his life for the same landlord, earning wages for the days that he worked and expecting assistance when needed. For his son's marriage, he received some grain, money, and a small plot of land from the landlord. After the conclusion of this transaction, called kamaiuti, the son, too, became the same malik's Kamia. Women also became attached to the same masters through the labour relationship of their Kamia husbands. Thus, women too, along with their Kamia husbands, worked in the paddy fields of the maliks and both were subjected to a system of the restrictions: restrictions on their movement, their labour, and their person. But ironically, it also lent a new lease of life to such techniques of domination. Because of the juridical constitution of the Kamia-malik relations as debtor creditor ties, an already indebted Kamia became a dependent subject of a munificent landlord when escalating transactions of gifts and service lubricated the relationship. Thus, the labourer with suspended rights also became a dependent subject of the patriarchal master who exercised domination through loans. physical violence, material rewards, and symbolic and ritual subordination.

In the past, according to Prakash ${ }^{24}$, the colonial government regarded this servitude in exchange for loans as an advance over slavery, it was perturbed by the

19. Breman, f.n.no.1.

20. Genovese, f.n.no.4.

21. Foucault, f.n.no.3.

22. Katherine N. Rankin "The Predicament of Labour : Kamaiya Practices and the Ideology of 'freedom', in Herald O. Skar(ed.), Nepal: Tharu and Terai Neighbours, Kathmandu : Bibliotheca Himalayica EMR Publications, 1999, p. 33.

23. Prakash, f.n.no.10, p. 1.

24. Ibid. 
continued existence of unfreedom. With history seen as a steady march towards progress, this suspension of natural rights to freedom appeared as an anachronism. Thus, it hoped that as economic progress occurred and modern education spread, the labourers would realize the value of freedom.

In the reproduction of Kamia-malik relations as ties between patriarchal masters and dependent servants, ${ }^{25}$ he has also suggested with respect to Bihar, bonded labourers may engage in subtle challenges to their masters' control, entirely outside the realm of juridical power. For him, Kamias thus become "not just persons to limit their landlords' control $^{26}$. While describing about the problems of culture contact, Srivastava ${ }^{27}$ stresses one of points, "Another practice rampant in some villages in debt bondage or bonded service, known as bonda...". The same system exists in Bombay to which Dr. Pilai has coined as 'a grestic serfdom' ${ }^{28}$.

The sanskrit term karmakara and Pali term kammakara refers to 'work for wages whose position was marked by debt relationship' and 'as one who earns his living for a bhatta-vetana, that is for cooked rice and wages for fixed periods' respectively. But they are distinguished from the dasa (slaves) ${ }^{29}$.

\section{Kamaiya in Nepal}

Debt - bondage is very popular in far Western Terai region of Nepal. The bonded labours or Kamaiya in this paper belong to the Tharus, one of the indigenous ethnic groups of Terai region of Nepal. After 1990, this system became a big academia and political issue. Since then many scholars, INGOs, politicians, and human rightists took interest and carried out survey and research in different Kamaiya (bonded labour) affected areas of Western Terai. Most of the works condemn this system and seek remedies. The scholars seem to be motivated from a "discourse of freedom" rooted in early modern political thought and the rise of capitalism in which political freedom is liked to the growth of self regulating markets.

However, the most important and remarkable aspect is that the question of Kamaiya system has been raised by the Kamaiya themselves. This may be for the first time the Kamaiya became aware of their status as bonded labourers. A close observation of Kamaiya affected areas and Kamaiya - landlord ties in different times from 1990 to 1999 was basically aimed at testing whether or not the imported model and indegenous ideas can go together. Similarly, it has been realised that until and unless a detail study is done, no suggestion and policy can affect in pre-modern and preliterate society. Therefore, realizing the situation an effort has been made to study the Kamaiya system prevailing in all above mentioned areas of

25. Ibid., p. 185.

26. Ibid., p. 183.

27. S.K. Srivastava, "Culture Dynamics Among the Rana Tharus", in Herald O. Skar (ed.), Nepal: Tharu and Terai Neighbours, Kathmandu: Bibliotheca Himalayica EMR Publications, 1999, p. 24.

28. Ibid., p. 25.

29. Prakash, f.n.no.10. 
Dang, Banke, Bardiya, Kailali and Kanchanpur of mid and far Western Nepal Terai. Only after close observation, a proper plan can be developed for the betterment of the Kamaiya according to the nature of Kamaiya system practiced in different districts of Nepal.

The household with a larger landholding size, from 5 to 10 bighas of land, in absence of sufficient manpower needs some labours to employ. Similarly, the landless family needs landlord to be employed there for indefinite period of time. In this system, the Tharu contracts loan from a landlord to meet his economic, social, religious and medicinal needs. Traditionally, the loan is taken in consideration of bond service and this does not terminate until the loan is repaid. This is a continuous process of being bonded labour from one landlord to the other because of being sold and bought by the landlords. Economically, the Tharus of whole Terai region are divided into four major groups: (i) Landlords, (ii) Peasants, (iii) Labours and (iv) Bonded Labours. In Terai, he who owns more than 10 bighas of land is called jimindar (landlord). He who holds minimum 2 and maximum 7 bighas of land is Kisan, the Tharus with inherently peasantry. A labourer is he who works on daily wage basis for a living. A labourer's source of income is on daily wages basis, which is a very limited and there are no other means to improve their economic condition. The labours hold small size of land (less than one bigha.). This category is found in Sunsari and Morang district. The haruwa, charuwa and tahaluwa system is popular in other parts of Terai. In those regions there is a tradition of employing haruwa (the ploughman), charuwa (the herder), tahaluwa (the watchman), and haliya or Kamaiya (the bonded labour). Those who are debtor and landless, they become the bonded labours, Kamaiya.

Broadly defined, the word Kamaiya means "earner"- someone works to earn a wage, either in cash or in kind ${ }^{30}$. There is also a tradition of woman working individually as Kamaiya, called Kamlhari. The landless labour either the entire family members or an individual is employed by the Kisan or jimindar in agricultural works at least for one year is called Kamaiya or haliya. Ethnically, the Kamaiya belong either to the Dangaura or RanaTharu sub-group. The Tharu Kamaiya work in the fields of Tharu and non-Tharu landlords (pahadi), on the basis of a renewable and mutually agreed oral contract for one year. If Kamaiya is not satisfied with his terms and conditions he can choose a new master. If another landlord pays off the debt, the individual or family Kamaiya must move to the new master's house and work there. A small family of non-Tharu group owning 4 bighas ( 2.68 ha ) of land is required to employ an individual Kamaiya, otherwise the Kamaiya is employed mostly by the jimindar. Often the jimindar function as local money lenders (mahajan) extending loans to needy farmers to observe social 
ceremonies, meet medical expenses etc. They are asked to mediate in disputes, to give final decisions on village matters, and represent in religious and ceremonial functions. Whenever a government official visits the village he is entertained by the local elite. In short, they dominate each and every aspect of the local power structure.

Gurung's field work ${ }^{31}$ reveals that some families have been working as Kamaiya for so many generations that they do not know how it all began and how they got into the debt chain. In this regard, the informants of Kanchanpur relate the story of the emigration of pahadi (the hill people) to Terai. The pahadi used to come down to the Terai in every winter season. During the whole winter, they used to live there. While staying in Terai, they, but not all, established ritual friendship, mit, with the Tharus. This miteri relations made easier for the hill people to take shelter in the Tharu's house. While staying with the Tharus, they worked, gambled and drank together. Due to the indulgence in gambling and drinking, the Tharu male members were constrained to take loan either from the Tharu landlords or pahadi mit or other hill migrants. The prevailing proverb, jahan Tharu wohan daru (where there is Tharu, there is alcohol), also highlights the above mentioned scenario. Later on, when they were unable to pay their loan back, they were compelled to sell land. Thus, they gradually became landless. Later on, the loan transaction became complicated because the loan swelled to larger amount. The Tharu mit was trustworthy whereas the pahadi mit was fraud. The lose-lose scenario in gambling encouraged to take more loan from the pahadi. Unfortunately, the poor Tharus did not think about their future. Finally, they were compelled to give their land to the pahadi in terms of repayment. But no evidence has been found among the Dangaura landlords exaggerating the amount of loan. However, the exploitation, it is suggested, continued for 15 years inspite of the eradication of Malaria in Terai. Even till 1989, there were a few cheating of the sincere Tharus of Terai. But, it is very difficult to generalize the whole pahadi who have bitterly exploited them. This study shows that the Tharus needed money and the pahadi needed land. Consequently, they sold land and became landless and later they were bound to be the Kamaiya . Due to the impact of urbanization, the Tharus gradually became poor because their children changed their earlier habit of drinking liquor, watching movie and buying fashionable and luxurious goods. In order to fulfill their desire, they needed money and decided to sell land in cheaper rates. Thus the decadence of rural life, directly affected the Tharus to change from

30. Ashutosh Tiwarai, "On Kamaiya", The Kathmandu Post, Daily English Newspaper, June 30, 1996.

31. Ganesh Man Gurung "Socio-economic Network of a Terai Village: An Account of the Rana Tharus of Urma-Urmi", in Ganesh Man Gurung (ed.), Indigenous Peoples Mobilization and Change, Kathmandu: Ganesh Gurung, 1994, p. 94. 
one status to another i.e. from peasant to bonded labour. In 1991, It was witnessed during research that three Rana Tharu boys became debtor and later on they were compelled to be Kamaiya due to their changed habits. Considering the situation, the money lenders realized that this is the high time for asking repayment which seemed almost impossible from the debtor's side and there was no other way out except selling the available land in the cheaper rate to the same money lender. Even the extra-money which they got was spent either in gambling or in taking liquor. Overall, the reason of becoming poor is not only due to the pahadi but also due to their own habits. This is how the Tharus became landless, homeless and finally became Kamaiya for survival. They have to offer bonded service to the house where they get employment for indefinite period. Other reasons of becoming bonded labour are large joint family, illiteracy and extravagance.

The household with small land holding size or even landless family has to be employed for their survival. When a senior male member of the family realizes that he is unable to supply food for his family, he decides to be Kamaiya to any household. Then he is in search of landlord and after finding him, he approaches him for loan in cash. If the landlord is also in need of Kamaiya, he agrees to extend loan in consideration of bonded service. Particularly, once he becomes Kamaiya, he should always be Kamaiya because it is almost impossible to extricate from the debt chain.

In the context of the Dangaura Tharu community, Tiwari writes ${ }^{32}$, there used to be strict division of agricultural labour. "Our tradition was that whenever there was a death in the family, the head of the house would bring in a Dangaura from outside and make him do the agricultural work that the deceased used to do." This indicates that the system of bonded labour might have begun from the same community since long. The non-Tharus also express that this system was prevalent in the Tharu community of Dang/Deukhuri and this tradition spread up to Kanchanpur along with the Tharu migrants. Later on, the hill migrants adopted this system without hesitation. Whatever the circumstances may have been theTharu Kamaiya is exploited by the hill migrants. Many changes have taken place in the Tharu community but the Kamaiya system is still in vogue in mid and far Western Terai.

\section{Kamaiya Population}

Regarding to the population of Kamaiya, there is no uniformity of record given by different sources. According to the Report of Backward Society and Education(BASE) ${ }^{33}$, there are altogether 35,874 Kamaiya and Kamaiya children

\footnotetext{
32. Tiwari, f.n.no. 30.

33. Backward Society Education (BASE), Kamaiya Report, Dang Tulsipur, 1994.
} 
registered in five districts of mid and far Western Nepal. BASE has categorised the whole Kamaiya into three groups which are as follows:

Total No. of Kamaiya

\begin{tabular}{|l|c|c|c|c|}
\hline \multirow{2}{*}{\multicolumn{1}{|c|}{ DISTRICT }} & \multicolumn{3}{|c|}{ GROUP } & \multirow{2}{*}{ TOTAL } \\
\cline { 2 - 4 } & $\mathrm{A}$ & $\mathrm{B}$ & $\mathrm{C}$ & 3.807 \\
\hline Dang/ Deukhuri & 1.272 & 570 & 1.965 & 2823 \\
\hline Banke & 2.070 & 325 & 428 & 10.569 \\
\hline Bardiya & 6.646 & 2.086 & 1.837 & 14.3 .4 \\
\hline Kailali & 6.511 & 6.012 & 1.781 & 4.371 \\
\hline Kanchanpur & 2.661 & 1.051 & 659 & 35.874 \\
\hline Total & 19.160 & 10.044 & 6.670 & \\
\hline
\end{tabular}

Source : The Report of Kamaiya, BASE, 1994.

Regarding the population of Kamaiya, in a survey completed in 1995, the government recorded more than 85000 from 16000 Kamaiya families whereas surveys conducted by NGOs (BASE and INSEC) estimated the number of Kamaiya population to 200,000 from 40,000 families $^{34}$. In one newspaper it is shown that altogether there are 6,968 families who have no land and shelter. Basnet $^{35}$ quotes that there are 7,945 Kamaiya population in Kanchanpur, 30,462 in Kailali, 25,864 in Bardiya, 6,846 in Banke, and 12,275 in Dang. There is found three different records of Kamaiya population only in Kanchanpur district viz. the government based committee shows 3000 Kamaiya families. The Land Reform office records 1663 and the NGOs records 4673 in the same district. This variation makes the people more confused. In can be imagined that the same type of variation could be in other four districts. ${ }^{36}$ In the case of Banke district the government authorities record that out of 342 Kamaiya families, 186 families do not have land and houses, 875 have houses with 2 katha of land and other 242 families (unknown) from the recent survey ${ }^{37}$. Similarly, the same paper quotes that there are 3,155 Kamaiya families having no houses. According to the source of BASE, there are 7152 population of 1000 families who have recently set the temporary camps in 24 areas of Kailali districts after their emancipation in July,

\footnotetext{
34. Ashutosh Tiwari, "Bondage to Freedom : Making it Work", Spotlight, July 25, 2000, p. 32.

35. Junar Basnet, "Kamaiya Fukka Jivan Yatra Kata? ",(Whether Liberated Kamaiya ?), Youbamanch, Year 13, No. 13, p.26.

36. Dristi Saptahik, Weekly Nepali Newspaper, September 5, 2000.

37. Gorkhapatra, Daily Nepali Newspaper, September 5, 2000.
} 
2000. It can be assumed that the average size of Kamaiya family is about seven ${ }^{38}$. So far, 705 Tharu families have been relieved off their debts by the government. Two years back, government had allocated Rupees five crores (Rs. 5,00,000,00) for making freeing the Kamaiya from the debt-bondage ${ }^{39}$. Out of the total number of Kamaiya families, 95 per cent are the Tharus. All of them are illiterate and suffering from diseases. Ninety two per cent of the Kamaiya have no land. Fourteen per cent of the Kamaiya are working at their relatives' house ${ }^{40}$.

In Kanchanpur district, an organization called Vedokta tatha Dharmik Sudhar Sansthan has recorded that there are 4,470 Kamaiya from 667 family in 10 out of 19 Village Development Committees and one municipality. An immediate Chief District Officer of Kanchanpur reported that there are 9,000 Kamaiya families in the same district. According to the report of Local Development Office of Kailali district, there are 5,430 Kamaiya families in 33 out of 43 Village Development Committees and one Municipality. The total amount of loan taken by Kamaiya is Rs. 6,16,256. Considering all these facts, the local people assumed that there should be Rs. 10 millions of loan taken by the Kamaiya from the landlords of two districts. While surveying in the field of Kanchanpur, in 1992, it is found that 11 out of 65 households of Asaina village have employed Kamaiya, out of which 7 household have employed 7 couple and 4 household have employed 4 individuals. Similarly, 4 out of 54 households of Wollo Kaluwapur village have employed 4 individual Kamaiya. In Sama Daiji village, 7 out of 35 households have employed 6 Rana and 1 Dangaura individuals as their Kamaiya. Altogether, there were 22 Tharu Kamaiya employed by the landlords among 154 households in three different villages. While inquiring about the loan, the highest amount was Rs. 12000/- and Rs. 800/- was found to be the lowest amount of loan. The two Kamaiya were giving free service for food without loan. They were employed through mutual understanding between the master and Kamaiya. Those two Kamaiya were the brothers of landlord's wives. From the survey, it has been found that 22 Kamaiya have taken loan of Rs. 55,000/-, which is Rs. 3,000/- loan per Kamaiya. So far as the Kamaiya data is concerned, the purpose of showing this data is to prove that they are employed not only by the pahadi but also by the Tharus. Only difference is that the Tharu landlords do not double the loan to the Tharu Kamaiya .

In Kanchanpur the landlords of studied villages reported that they have to spend minimum of Rs. 7,000/- and maximum Rs 60,000/- for employing the Dangaura Kamaiya. There were found few Kamaiya in Dangaura Daiji village of Kanchanpur district who had already taken Rs. 52,000/- to Rs. 60,000/- loan from the masters. However the majority of the Kamaiya's average loan was found in-between Rs 12,000/- and 18,000/-. The question comes after becoming a

38. Raja Ram Gautam, "Kamaiya Mukti Le Kisan Pani Marma Pareka Chhan" ( Kamaiya Liberation Has Affected Peasants), Nepal, 1-15 Ashwin 2057 (2000).

39. Kantipur, Daily Nepali Newspaper, Feburary 12, 2000.

40. Samakalin, Weekly Nepali Newspaper, December 17, 1998. 
Kamaiya as to what facility he gets from his landlord. In this regard, the non-Tharu landlords expressed that they provided the same facility which is provided by their own community-the Tharu landlords.

\section{Female Kamaiya}

While inquiring about the women who have become Kamlhari in Deukhuri the individuals are paid Rs 2000/-3000/- and a pair of garment annually. During the presence of researcher, a non-Tharu of Deukhuri took a Tharu girl as Kamlhari to Kathmandu paying Rs. 4000/- providing food, clothes and shelter. The other Tharu girls are also sent to Bhairahawa, Butwal, Pokhara and Kathmandu where they feel convenience to work as Kamlhari. Those who work as Kamlhari in the native areas, are given traditional payment in terms of thanka (30 mound of grains) and maseura (36 mound of grains). The house where they are given service they are provided food. They also get one pair of clothes annually. It was also noticed that the Kamlhari are given assurance of providing education as well as beautiful clothes by the landlords. But few guardians noticed that their daughters were not getting any facilities from the landlords. The Kamlhari work at landlord's house throughout the year only with having food and clothes.

When the landowner requires man power to husk the rice, the Kamaiya's wife is first called. It is she who participates in this work called Kutnahari. She will take 8/9 days for this work. The Kutnahari gets food from same house for the working days.As she works as Kutnahari, she gets one mana (half kg.) of rice out of nine mana (4.5 kg.) rice. After completing the work at landlord's house she has no restriction of working in other place for earning purpose. In the month of Jestha the rice husking activities are followed in the villages. The work begins from 30 ' clock in the morning and stops it around 3 p.m. Mostly the wife of Kamaiya in the Rana Tharu community has to work as Kutnahari. If she goes to grind the musur (Lens culunaris), she is called pisnahari. She continues working until the harvest is complete. In its return she gets one daliya (approximately $8 \mathrm{~kg}$.) of musuro. She is also called for wheat harvest which takes 4 to 5 days. In its return she gets one katta (sack) of wheat. She should also go to work at the time of mustard harvest. In such a work the household members also go to the field for harvesting. It does not matter how many days does she work, she is given 5 litre of cooking oil.

The Dangaura young unmarried girls aged between 8 and 16 are sometimes taken to work exclusively in their landlord's house and are referred to as orgoniya in the Kamaiya system. Such girls are vulnerable to sexual abuse. The sexual abuse of women bonded labourers is widely acknowledged but individual cases are seldom reported. In one infamous case from a village in Bardiya district, every newly-wedded Kamaiya bride had first to sleep with the village landlord on her wedding night. The landlord concerned was later humiliated when the story came to the attention of the wider public, but he has never received any formal punishment $^{41}$. In the off season, they (the Kamaiya) are either given other work or

41. Adam Robertson and Shisham Mishra, Forced to Plough Bonded Labour in Nepal's Agricultural Economy, Kathmandu : INSEC, 1997, p.24. 
are loaned or hired to their landlord's friends or relatives. ${ }^{42}$ The Report of Kamaiya prepared by $\mathrm{BASE}^{43}$ has also shown the same type of situation.

In the Rana Tharu community, there is a tradition of employing the girls for grazing the sheep and goats. Professionally such type of girls are called bakareheri who do not work in the field of landlord. Rather they are approached to do light work at home. As being the bakareheri, she gets equal set of clothes as that is provided to the other female members of the family. She is also provided food at the same house. These days, due to not having pastures and increased number of school goers, the percent of bakareheri is being gradually decreasing. There is also the tradition of employing the girls as house cleaner known as lisnahari. If they are employed from the same village, they are simply provided food, otherwise extra one set of outfit is provided to those who use to come from outside the village. Another type of employment is called dhan katani. This type of employment is generally given to the ninhariya. Somewhere this kind of job is offered to the poor girls of one's own village too. However, all those employees are not counted as the bonded labours.

\section{Kamaiya Typology and Nature of Employment}

The Kamaiya are generally employed in three ways : one is the group of Kamaiya who is economically handicapped and seems unable to meet their daily needs, takes loan, saunki (used by the Dangaura), or saunpi (used by the Rana) from the landlords and the whole family of this group goes to the landlord's house to provide service where the family is provided half kattha (6 anas) of land for housing and gardening. The small house, bukhra, is built by the landlord for the Kamaiya to live and work for them until they are able to repay their loan. This is popular in Bardiya, Kailali and Kanchanpur. In Bardiya, the former is known as bukraha Kamaiya and in the latter system the labourer stays with his landlord who provides him with a thatched hut to live in. Upon joining the landlord, the labourer is paid nine bags of unhusked paddy, each containing 75 kilos, and 10 kilos of salt. At the end of the year, the labourer and his wife are given a set of clothes each. They also receive one katha (one-twentieth bigha) to grow vegetables for their own consumption. After the planting of the paddy as well as after the harvest, the Kamaiya and his family are entertained with drinks and delicious food (harduwa) for two days. In case the Kamaiya gets the control of one-fourth of the land to cultivate at his own discretion, he is obliged to serve his landlord a festive meal (mizeni) once a year. ${ }^{44}$ This reveals that the household belongings of Kamaiya are also supported by the landlord at their own expenses. The Kamaiya while staying at landlord's house, might face many problems like the daughter's or son's marriage, festival expenses, remedial treatment, extra clothing and fooding which need money. In order to fulfill the social and cultural needs, they once again ask for

42. Ibid., p. 20.

43. BASE, f.n.no.33, p. 10.

44. Sven Cederroth, Managing the Irrigation Tharu Farmers and the Image of Common Good, Sweden: Nordic Institution of Asian Studies (NIAS), 1994. 
money as a loan from their masters. This loan is gradually increased year after year. In this regard, the Report of $\mathrm{BASE}^{45}$ describes that the debt increases 5 per cent each due to the immense interest rates decided by landlords and the money lenders. But, it was reported in the field that the master does not take interest in the loan. The service given by the Kamaiya is equivalent to the interest of the loan. The important thing is that the Kamaiya will be ignorant of the actual loan and of how much the landlord writes in his pocket note book.

The second group of Kamaiya are employed on individual basis. Such type of employees get regular food at the landlord's house. As they work as Kamaiya, they get bohada (4 quintols of unhusked rice) in terms of clothing, salt and cooking oil. Though this is not sufficient to their family, the Rana Tharu Kamaiya do not react with this system. This is generally practiced by the Rana and Dangaura Tharus. As the Report of $\mathrm{BASE}^{46}$ shows that this group of Kamaiya always live in fear of losing the land they cultivate. Until their land is registered, insecurity is bound to endure. The other system of bonded labour in Rajapur of Bardiya is known as kutuwa Kamaiya. The basic difference with the first type of bonded labour is that under this system the labourer does not get any land to cultivate, but a fixed amount of paddy, usually some 600-750 kilo, as a salary. In addition, he will also get some 30-40 kilo of the vegetable crops grown. This amount, however, is not fixed but depends upon the yield and the goodwill of the landowner ${ }^{47}$.

The third group of bonded labourers who are indebted and live in their own homes. They own registered land, 1-2 kattha (1 kattha -3,645 sq. ft.), because of the land reforms in 1964. They are unable to fulfill the basic needs and demands of their families. This is the reason why they have signed a contract with the landlord ${ }^{48}$.

In Deukhuri, the Kamaiya are entitled to (a) chharwa (b) thekka or bighawala and (c) Kamlhari. A chharwa is he who gets 10 katthas of land from the landlord. Besides, he can grow blackgram, mustard, paddy, wheat, maize and peas. Though this system is popular, these days people have started working on daily wages basis. It is he, who works under the thekka system, will not get those cereals. Those who compromise to work at the landowner's house throughout the year by charging money called thekka. If not he is given thirty to forty mound of grains annually with having food at the landlord's house. During fieldwork, it was noticed that twelve Kamaiya were working under this system. The third type of group belong to individual girls or women who compromise to work at landlord's house throughout the year on annual salary basis or certain amount of grains as mentioned earlier. In Deukhuri, out of 200 households, 25 household are owning 5

\footnotetext{
45. BASE, f.n.no.33.

46. Ibid.

47. Cederroth, f.n.no.44.

48. BASE, f.n.no.33.
} 
kattha of land, 50 households are owning one bigha of land and the remaining households are owning 2 to 5 bigha of land.

In Dang, there is a tradition of working at landlord's house by taking 12 to 14 muri (10 quintol) of grain with a meal at one's own home and 8 muri of grain including meal at landlord's house. In one village of Dang, the informant noticed that the Kamaiya gets 20 to 25 muri (17 quintol) of grain without food and 10 to 14 muri of grain with food. The landlord provides 12 paseri to 2 mound of seed to the Kamaiya for sowing it in the given land (approximately 10-15 katha of land). $\mathrm{He}$ is also fed at the landlord's house. For example, if the Kamaiya works at one bigha of land throughout the year, he is also given Rs. 1600/- per year. If he works at 4 bigha of land, he gets Rs. 6400/- per year. If the Kamaiya has food in his own house he is given Rs. 1800/- per year.

In the Rana Tharu community if there is only one couple they prefer not to be Kamaiya. In order to maintain their livelihood they follow labour work from which they earn money and buy grain. This daily wages basis is called dehari. In this community, they mostly prefer to employ Kamaiya from their own community. Mostly it is found that either the relatives or the neighbours are employed by the Rana Tharus. Thus, a Rana Tharu gets employment easily, and a poor Rana Tharu highly benefits from the system of own communal tradition. There is always a close relationship between the landlord and Kamaiya in the Rana Tharu community. In comparison to the Dangaura Kamaiya, the saunpi (loan) of Rana Tharu Kamaiya seem to have very low amount. Most of them have been indebted to the Kisan and the amount of debt falls between Rs. 300 to Rs. 10,000 ${ }^{49}$. But, in Kanchanpur, majority of the Kamaiya's loan was between Rs. 3,000 to Rs. 7,000. Comparatively, a very few Rana Tharu have become Kamaiya to the Dangaura and pahadi landlords. Rather it is found that many Dangaura Tharu becoming Kamaiya to the Rana landlords. As far as the Dangaura Tharu are concerned, they are employed to the Dangaura and pahadi landlords.

Still today, there are some differences in the treatment of the Kamaiya between what is known as 'old' and 'new' landlords, respectively. An old landlord is a person who held land before the introduction of the land reforms in 1964, whereas a 'new' landowner refers to a person who got his land after the reforms. The main difference is that a 'new' landlord will expect all members of the Kamaiya family to work for him without any additional payment whereas under the old system only the man and his wife were forced to serve ${ }^{50}$.

\section{Kamaiya Survival}

So far as the nature of employment is concerned, if the Kamaiya are employed by the pahadi ,they get one kind of wages and if they are employed by the Tharus they get little different kind of wages. In the pahadi system, a Kamaiya gets 7 quintol of unhusked rice as maseura per annum. The term maseura means a

49. Ibid., p. 93.

50. Cederroth, f.n.no.44. 
kind of fixed amount of grains given to the man who provides his service to his landlord. This is primarily concerned with person. In 1991, the cost of seven quintol of unhusked rice was Rs. 2100/-. Besides providing maseura, the Kamaiya also gets one bigha of land from the landlord. Traditionally, the Kamaiya provides his whole service to the landlord during the time of cultivation and only after then, he can work at his given land for cultivation but by that time the agricultural time is already over. This might affect to grow proper amount of grain. By realizing this problem, the Kamaiya takes four quintol of unhusked rice in terms of bohada, as his wage. Thus the Kamaiya gets bohada (4 quintol) and maseura from the landlord. Over all, there will be 3.5 quintol of rice from 11 quintol of unhusked rice. This amount is not sufficient enough to feed family of six for a year. As a rule, one seer of rice is cooked daily for the Kamaiya, this is true in Kailali and Kanchanpur $^{51}$. The daily consumption of rice by the Tharus is very high, 1 seer per person per day being considered normal, Tharus frequently eat rice three times a day $^{52}$, besides he has to buy cooking oil, clothes, salt and other food stuff. Thus, a Kamaiya incurs considerable debts in course of providing service to his landlord. In such a situation he is forced to seek another master to get himself relieved from the present master. In this way, the Kamaiya becomes life long debtor and economic burden increases on. Cederroth ${ }^{53}$ also writes, a strategy to tie them to the landowner's household is to make them heavily indebted. Non-Tharu landlords also force the Kamaiya to pay high interests (up to 60 per cent a year ) on such debts. Since, as a rule, the Kamaiya are illiterate they are easily cheated on such debts by deceitful landowners. This enforces the Kamaiya to change his loyalty and honesty for his master. In so many pahadi household, the Kamaiya are employed only on the basis of bohada system.

In Kanchanpur, one Kamaiya reported that he is given only 5 quintol of unhusked rice and old clothes per year. But there are also some landlords who provide bohada, maseura, 4 litres of cooking oil (Rs. 400/-), $40 \mathrm{~kg}$. of salt (Rs. 100/-), medicine (Rs. 200/-), clothes (twice a year) equivalent to Rs. 2000/-, dari (Nep. satranja or Indian carpet), and kammal (Indian blanket equivalent to Rs. 400/-) to the Kamaiya. Comparatively this does not show that the Kamaiya has been exploited by the landlord.Therefore, a Kamaiya gets the total amount of Rs. 6000/- per year from the pahadi landlords. In the Dangaura and Rana Tharu community the Kamaiya is provided 3 bigha of kacha (unproductive) land by the landlord of the same group. At the time of harvest, the Kamaiya is advised to cut paddy from any section of 3 bigha of kacha land. Besides giving 3 bigha of kacha, uncultiviable land, he is given one rug in Ashad (June - July), one coat and dhoti in Mangsir (November - December) and some masters might provide one pair of shoe. The Kamaiya produces minimum 6 and maximum 8 quintol of rice from the field. Similarly he produces approximately half quintol of mustard seed, 1 quintol

51. Charles McDoughal, Village and Household Economy in Tharu Western Nepal, Kathmandu : Tribhuvan University, 1968, p. 89.

52. Ibid., p. 110.

53. Cederroth, f.n.no.44. 
of maize, and 1 quintol of wheat. But the Kamaiya do not get this facility from pahadi landlords. According to Gurung ${ }^{54}$, in regard to the preference towards the choice of a master between Pahadiya and Tharu, most of them gave preference to a Tharu master. A few of them expressed that it is easy to get their adjustment with a Tharu master because they belong to the same ethnic group and speak the same language. During the peak period of the year, those lobourers work approximately 18 hours daily in a week. They are overworked, for which they are not paid for. There is also a marked difference in the treatment of the bonded labourers by landowners who themselves are Tharu and by those who belong to other communities. This is especially true in those cases where there is some kind of relationship between the landlord and his Kamaiya. Even where there is no such relation, the Kamaiya usually gets much better treatment from members of his own ethnic group. For many non-Tharu landlords, it is a matter of prestige and status to keep as many Kamaiya as possible ${ }^{55}$. There is similar system of providing clothes to Kamaiya once a year by all Rana, Dangaura and Pahadi landlord.In the case of Kamaya's wife, Roberston and Mishra ${ }^{56}$ write that the bukrahi (the wives of Kamaiya ) work in the landlord's home as domestic servants, but also process farm produce and work in the fields at peak times. In case, if she has to work at other time particularly in the dry season, she gets 10 to $19 \mathrm{~kg}$. of unhusked rice as her majuri which is equivalent to Rs. 30/-. Therefore, all the family members, except Kamaiya (one person), take their food at their own home. Generally, both Kamaiya and landlord seem working together during the time of cultivation and harvesting. The employee takes two meal at the same house and goes back to sleep at his own home. This is in Rajapur of Bardiya.

The first year the employer provides 1.5 mounds of paddy as seed (the standard amount sown by Dangaura Tharus on 1 bigha of land), and usaully a small amount of maize and mustard seed. In subsequent years, the labourer must provide the seed from his own harvest. In the Rana Tharu community, about one-third of a bigha is provided for the labourer's use, but every year seeds are provided by the employer. The labourer is also provided clothing. In both the Dangaura and Rana Tharu system, the labourer must be provided with food everyday, even if he is not required to work ${ }^{57}$. Kamaiya of bukraawhaa are excluded from village committee $(\mathrm{khel})$. What is noticeable here is that it does not mean they do not belong to the village community as a social unit, since they participate in village ritual arrangements ${ }^{58}$.

54. Gurung, f.n.no.31.

55. Cederroth, f.n.no. 44, pp. 7-8.

56. Robertson and Mishra, f.n.no.40, p.21.

57. McDougal, f.n.no.51, pp.81-83.

58. Christian McDonaugh, "Aspects of Social and Cultural Change in a Tharu Village Community in Dang, West Nepal, 1980-1993", in H.O.Skar (ed.), Nepal: Tharu and Terai Neighbours, Kathmandu: Bibliotheca Himalayica EMR Publications, 1999. 


\section{Kamaiya's Agony}

The Kamaiya do all the ploughing and heavy work in the field. During the time of cultivation and harvest, they usually work for 12-hour continuously in the field. Dangaura Tharus mostly eat their meals in the fields where they work. This enables them to save time and not to waste it by going back and forth from the fields to their houses. However, realizing the exploitation of the Kamaiya, those bonded labourers along with some non-Tharus formed a group called Bhatpuri Haliya Sangh (Bhatpuri Ploughmen's Association) in Kanchanpur under the leadership of a non-Tharu landlord Bimal Bist. He wrote one pamphlet entitled Garibko Aawaj (Poor's Voice) in 2039 B.S. (1982) and distributed it in the district. One of the paragraphs of the pamphlet speaks about "We will not say, provide us food by confiscating the original property of the landlords. We demand only the proper wages of our labours. We (haliya) are afflicted with illness and then live always in a state of anxiety of fears. We weather away in the range we get scorche in the sun and shiver with cold in the winter. We have been treated as commodity as that is bought and sold. We have been working for paying the interest of the loan we have taken. We are barely making a living. A living labour has become synonymous with our daily life. We have to mortgage our honesty. ...The hard working, entire of ours, has to be dedicated to the landlords. Inspite of that, we barely get enough food to eat and clothes to wear. On the contrary, the landlord with evil intentions double to buy the forgery amount of loan that we have taken. The landlord spent a life of luxury and comfort. But our own response to this is that we want to rise and breathe the fresh air of liberty." This clearly reveals that the voice of Kamaiya was already raised by the non-native in the Panchayat period.

\section{Continuity and Change}

A Kamaiya until he pays back his loan has to continue to work for his master. Many Kamaiya of Kanchanpur district have been staying at the same house for the last 12/15 years because they are unable to pay back their big amount of loan. It is said that when the Kamaiya cannot pay his loan back, he is ill-treated by the landlord. Due to his huge amount of loan, no new master seems ready to employ him as his new Kamaiya. But while changing old master, there is no enmity between the two. In principle, the contract lasts for one year till the end of Poush (29 December). The new master and Kamaiya are mutually agreed upon the oral contract by the third week of January for a year. The Tharus observe a big festival known as maghi (in the third week of January). Few days before the festival, there is negotiation between the present master and Kamaiya. In the discussion, if the Kamaiya is not satisfied with his terms of condition, he does not compromise to renew his job. The master also makes the account clear and allows him to search out the new master along with the amount of loan with a piece of paper. This kind of negotiation is known as khujhani bujhani. Realizing the importance of maghi festival of Dangaura, the landlords leave their Kamaiya to celebrate this festival for five days. If he has decided to leave his master, he is free for three to four days for searching out the new master immediately after the festival. For this, he is given Rs. 50/- in advance. If another landlord pays off the 
debt, the Kamaiya family must move to the new master's house and work there. In the Rana Tharu community, till before 1979, if the Kamaiya wanted to choose the new master, he used to leave him immediately after harvesting. But after 1980, the Rana Tharus also recognized the same festival for employing the Kamaiya.

In order to find the new master, the Kamaiya visits different places along with one stick and blanket.Actually, the stranger with stick and blanket symbolises that he is a Kamaiya searching out the new master on the occasion of maghi festival. The reason of taking stick is to protect himself from dogs and blanket for night halt. From these attributes, the local people easily recognise the stranger as Kamaiya who is in search of a new master. The stranger is first asked about his loan. If the new master is satisfied, there is an oral agreement between the two as mentioned above. Then he is employed as new Kamaiya to the master for one year. In case, the new master refuses to pay the mentioned loan and the Kamaiya cannot find the new master within the time, he goes back to his previous master and continues the same job. This is accepted by his previous master. From this point of view, the Kamaiya seems always safe and secured.

As an institution, Kamaiya is a continuous process. Only the important thing is that the master is changed but, the situation remains unchanged. At the time of employing Kamaiya, there is no tradition of making mortgage. This is simply mentioned in the note book of the landlord. According to the masters, mostly the Kamaiya, except a few, seem to be honest and sincere. There are a few Kamaiya who do not pay keen attention in farming because it does not affect the Kamaiya's family. No matter, whether there is grown good crops or not, the Kamaiya will get fixed amount of grain as usual. Therefore, they should not bother to yield the good crops. This is negative part of the Kamaiya. Even the Kamaiya do not share the grain properly. In the absence of landlord, they also sell some amount of grain. This is not known even to the landlords because they live far from their native place. Besides, they consume much amount of grain in drinking fermented liquor. Some masters reported that the Kamaiya who were providing service since last six to ten years flew to India without any notice. If this happens, the master will not get his loan back. This generally happens when there is misunderstanding between the master and Kamaiya. During fieldwork in 1991, two Kamaiya left their masters and fled to India. When this was known to the other masters, they forced their Kamaiya to work for the whole day and in the following evening they would be locked up in one room of the house for not getting chance to flee to India. In this regard, another group of informants expressed that this was natural because the Kamaiya would not get even the fixed amount of grain. A few landlords generally provide their wages in partly basis and having frustrated, the Kamaiya decides to run away from the master without any notice. Due to illiteracy too, the Kamaiya cannot react anything about the landlord's behaviour.

This indicates that the Tharu as Kamaiya of Nepal Terai are not the slaves. Rather it can be said that they are free slaves. The slaves cannot leave their masters but the Tharus, if they like, they can easily leave their masters. The Tharus are time 
bound bondage with lot of space. The Kamaiya seem to be moving every year from one master to another master reveals that they follow their traditional nomadic life.

\section{Etic Approach}

When multi-party system was declared in Nepal in 1990, most people were affiliated with different political parties. Consequently, the Communist Party (then CPN- UML) influenced the Kamaiya. Contrary to this, the landlords joined Nepali Congress Party and then Rastriya Prajatantra Party (RPP)and the Communist Party wooed the Kamaiya to make them free from landlords. As CPN-UML raised the voice in local level that the government should provide 4 bigha of land to each Kamaiya family with free of cost. This political slogan influenced the heart of Kamaiya. Accordingly, the Kamaiya became more ambitious and some forty to fifty Dangaura Kamaiya individuals formed a group in Mahendra Nagar and demonstrated against the Kamaiya system and of course against the landlords. Their demand was hami lai khana badhi de (provide us more food). Another slogan given by the Communist Party was "haliya's eyes have opened." Actually, the system then became quite complicated in Kamaiya influenced areas. The landlords were quite anxious during the movement.

Most of the landlords were confused with the transitional situation of 1990 and 1991. Observing the role played by the political leaders and the Kamaiya's activities, the landlords were confused about the Kamaiya's movement. This became the subject matter of discussion at the tea arena. Every one seemed waiting for the first election and after 1990 because of the hope that future government would launch some new policies regarding the Kamaiya. During their discussion, some non-Tharus viewed that the Tharus being illiterate have to work for their survival. Even though the Tharus are educated, they are unable to get any decent or respectable jobs anywhere. Due to the unemployment problem in the country they too suffered like the rest of their country folks. One of the pahadi reported that two Kamaiya were employed by the landlords of Mahendra Nagar and paid them Rs. 21000/- each, and after 1990 the Kamaiya requested the landlords that they would prefer to work only during day after the situation changed. This made the masters frustrated. In the same discussion, one of the participants opined that the government should pay 4 crores Rupees (Rs.4,00,000,00) in terms of saunki to make the Kamaiya debt free from the masters and they should be hired for Rs. 500/- to 600/- monthly. But, the government was not in position to pay that much amount only in one district. Moreover, people would hire only adult male members and not female ones. Inspite of their earnings of Rs. 500/- to 600/- per month, he viewed that it would not be sufficient to meet the needs of their family. If the system is to be abolished, it would be better to give land to the other hill migrants on the basis of share-cropping system, bataiya, instead of employing new Kamaiya by paying huge amount of saunki. He was very much optimistic of such system because the share-cropper might have more dedication to produce much more amount of grain which would make benefit to both sides. Another view against the former one was that it would be better if the land is given to the desi (Indian) for sugar-cane farming on the contract basis. According to his experience, 
the pahadi produced 500 quintol of sugar-cane from one bigha of land whereas the desi produced 700 quintol from the same size of land. From this, the landlord would be more benefitted from new alternatives. However, every one charged the hill migrants as Kamaiya exploiters. This is how the landlords were trying to develop several alternatives regarding their peasantry system. This was their view prior to the election.

\section{From Euphoria to Disillusionment to Antagonism}

When the election of 1991 was over, Nepali Congress got majority and formed the Government. Very few Leftist groups won election in far Western Nepal, known as the region inhabited by the Kamaiya in the Terai. A few group of Kamaiya encroached some parts of the forest areas of Kasrawal, Hirapur and Bhatpuri, the part of Suklaphanta Wild Life Reserve. At the same time, the forest guard put them under custody for their illegal activities and a few group of Kamaiya in Mahendra Nagar protested against the government's such action. The demonstrators also demanded to get their people unfettered from the custody. Finally, their attempt was in vain. They then committed with the government that they would not repeat the same activities. However, other people expressed that the Kamaiya movement without any reason created a great misunderstanding between the masters and Kamaiya. Regretfully, the same Kamaiya went to their former masters to get the same job but the masters paid no heed to their cry. As such, some of them worked on daily wages and some agreed to work only on the basis of bohada per annum. Then, there remained complete silence in Kanchanpur for about six-seven months after the election. During fieldwork, one CPN-UML activist provided membership to each Kamaiya by charging Rs. 4/- . Out of Rs 4/only, Rs 1/- was sent to the account of CPN-UML Kamaiya Association. This was keenly observed by the activists of Nepali Congress and RPP criticised that the UML policy of raising the voice for the poor people and ironically charging Rs. 4/from the same poor mass in the form of disguised exploitation.

For the first time after 1990 the history of Kamaiya's movement began from Pokhara. The Nepal Peasant Association's third National Convention was held in Pokhara in September-October, 1990. In that convention the representatives of Dang, Banke, Bardiya, Kailali and Kanchanpur participated and raised a voice against the landlords who have exploited the Kamaiya of five districts of western Terai. After then, there was held another meeting at the Auditorium Hall of Tribhuvan University, Kirtipur in December 1990 where some representatives of Human Rights organizations and the CPN-UML discussed on the problems of bonded labours and decided to conduct the survey in five districts of mid and far western Terai of Nepal. Immediately after this decision, INSEC, BASE and the government carried out survey for collecting the Kamaiya data in all five districts of western Terai.

In the first session of Parliament, 1992, the CPN-UML M.P. Keshav Badal tabled for dismissing saunki of Kamaiya. To help ascertain that the Kamaiya system is indeed bonded labour, in the course of its 1992 survey, the Informal 
Sector Service Center (INSEC) looked for the following characteristic traits: excessive work and working hours, insupportable (or no) remuneration, absence of negotiation, restrictions on movement and assembly, lack of opportunities for educaton, endurance of force and physical threat, and debt transactions among landlords. Among the methods landlords reportedly used to discourage the survey were: forbidding the Kamaiya from speaking with the surveyors; lying to the Kamaiya about the identity and purposes of the surveyors and to the surveyors about the presence and living conditions of the Kamaiya; threatening, pressuring and confusing the Kamaiya; and monitoring their answers (or answering on their behalf). For these and other reasons, INSEC inferred that estimates of instances of abuse, threats and sexual exploitation were seriously under-reported, yet it still found them statistically significant.

In its more recent survey, and through its ongoing work with and monitoring of the situation of the Kamaiya, Backwards Society Education (BASE), a grass root human rights and development organization founded in Dang district by Dilli Bahadur Chaudhary, has recorded numerous cases of suicide among Kamaiya, with young women at greatest risk. In 1993 on one day alone, seven young women committed suicide. Yet, because of their psychological vulnerability and conditioning, some Kamaiya think these studies and proposals for reform are futile and unrealistic, if not a direct threat to the little security they have. In 1995, there was organised a big rally in Nepalgunj. In that rally several members including Kamaiya, Human Rightists, politicians, NGOs and Trade Union Federation raised the voices against the Kamaiya exploitation. Finally there formed a committee which recommended to liberate the Kamaiya, their rehabilitation, proper wages, training and education to be provided to the Kamaiya. During the government of CPN-UML, Prime Minister Manamohan Adhikari established a commission to investigate possibilities for land reforms that would benefit the Kamaiya, but the task of the commission had only just begun when Parliament was once again dissolved in August 1996. Again in 1997, ILO, UNICEF and Trade Union Federation formed another committee to work for the betterment of Kamaiya. Since the election of 1992 the major political parties gave higher emphasis on the bonded labours' problem in their election manifestos. But no major steps were taken by those political parties.

During 1990-94, however, government initiatives were focused on a highly limited scale extension of educational and vocational opportunities through training to the Kamaiya. But the training remained incomplete and the trainees could not compete in the labour market. Many of them suffered because they were left on their own and extremely unsecure. Such situation created considerable dissatisfaction against the government and the Kamaiya came to the streets to protest collectively ${ }^{59}$.

In 1996, with great repentance the same informant Kamaiya of 1991 expressed that they were used as tool by the political leaders for their election

59. Nepal Human Development Report, Kathmandu : Nepal South Asia Centre, 1998, p 113. 
marathon and became potential resources for the so-called Kathmandu based researchers and development agents. Their further comment was that Kamaiya had been used as political tool to create the vote bank. Whoever visited the Tharu areas ostensibly raised voice for Kamaiya liberation with the hidden agenda of exploiting them. After the restoration of Multi Party System, several voices were raised from different corners in favour of Kamaiya which made them, in fact, more ambitious. Thus, the poor Kamaiya furnished euphoria to get liberated from the existing system for ever. The informants further expressed that the problem which they were facing before 1990 are still facing the same. This reveals that antagonism has increased at large among the Kamaiya of mid and far Western Terai. It has turned into a grand fiasco or anticlimax. As a result the bonded labours are disillusioned from the dream merchants especially on the left. The government in the past had tried to free these bonded labourers by paying off the debt to the landlords under a programme. In 1998 the government through a cabinet decision decided to set up a fund of Rs. 50 million to pay back loans as part of the bonded labour Debt Relief and Upliftment Programme. But the programme drew much criticism saying that the government was trying to buy these people back that it was involved in trade of human beings by making illegal payments to those landlords instead of punishing them for violating human rights of these bonded labours ${ }^{60}$.

In 1998, as one native expressed that politically bonded labour movement has proved to be the proverbial "much cry little wool". The effort of NGO-INGO has become a drop of water in the ocean. A few informants further expressed that the Kamaiya are sold not only to the landlords but they are also sold to INGOs and NGOs. The Kamaiya have become very good excused for earning money to those who are involved in NGOs and INGOs based in Kathmandu. Another group of informants expressed that only a handful Kamaiya are benefited from some INGOs and NGOs services. This will be no permanent solution as mentioned above.

\section{Preventive Method}

Though research has been carried out by several NGOs, INGOs and Government wing as mentioned earlier, they have collected no unanimous data of Kamaiya, their loan, their category and system as mentioned earlier. First and foremost, research should be done in detail from Deukhuri to Kanchanpur for the purpose of finding exact Kamaiya census, their loan and their category. It is necessary to know whether there is uniformity of Kamaiya system in all five districts or not. Only the uniformity of contract and renewal of Kamaiya on the occasion of maghi festival around. Otherwise, the types of Kamaiya and their treatment varies from district to district, village to village, ethnic to ethnic and sub-group to sub-group. Therefore, the development schemes should be prepared according to the nature of Kamaiya system. Simply taking census of the Kamaiya once within the decade will not work for the development scheme. Rather it makes more confused because the Kamaiya are renewed and changed every once a year. Therefore, the ward of the Village Development Committee must maintain record

60. The Kathmandu Post, July 18, 2000. 
every year after maghi festival. If it could be done scientifically, there will be no problem of making action plan for the betterment of Kamaiya. Second, there should be one Kamaiya registration office in every Ward of Village Development Committee. All Kamaiya must be registered in the office. There should be a system of making mortgages of saunki properly by both sides before the official staff and that should be preserved by all three corners like Kamaiya, landlord and local authority. This rule helps the Kamaiya because the bad master cannot exaggerate the amount of loan. If it is practicable, a photo of the Kamaiya should be kept in the office for his record which discourages him to leave his master without any notice. If this system is strongly legalised, the Kamaiya's regular service will be equivalent to this loan within $4 / 5$ to $7 / 8$ years according to the nature of saunki and after then they will be liberated from their masters. Then, if the Kamaiya does not wish to continue his service to the same master, he may work on monthly basis. If modern agricultural tools and technology are introduced in the mentioned areas, no peasant would require man power. The local or Agricultural Development Bank should be able to provide loan to the peasants and Kamaiya in low interest rate. If it can be done from the side of government, this partly helps to stop the people from becoming Kamaiya . If government provides free education up to higher secondary level,the educated youngsters would get chance to work in Nepal Police Force, Royal Nepal Army, Schools, and other related local institutions based in district level. Even INSEC ${ }^{61}$ has also viewed that 'the problems of Kamaiya shall not come to an end simply by giving physical assistance by one or two social organizations, running of literacy classes or some income generating schemes'. In order to liberate Kamaiya, the attention of the state towards their problems has also to be drawn. If this system is immediately abolished without any plan and programmes, the question arises, how does a Kamaiya survive ?. Solution to this problem is not an easy task-once he is liberated-what then ? It affects not only his whole family but also to the country itself. In the absence of man power in terms of Kamaiya, there will be no production of crops where still agricultural system is based on traditional methods. The problem of the Kamaiya, however, does not encourage the planners to abolish this system immediately until and unless the government itself is capable to repay the loans and manage to provide food, shelter and employment to the Kamaiya. Rather, it would be better if the planners, policy makers and local authorities launch some effective programme to keep the youngsters busy so that they refrain them from gambling, drinking alcohol and loitering aimlessly. This would help the younger generation for not taking loan from the landlord and would not have to sell their land to the landlords. If the landlords, according to the nature of employment, are agreed to increase the reasonable amount of maseura and bohada like 10 quintol and 6 quintol instead of 7 and 4 respectively for family Kamaiya, there would be no disharmony between the two. Besides, the preventive strategies should also focus upon literacy, primary health care, family planning, schooling, cottage industry, agricultural farming like

61. INSEC, Plight of the Kamaiya: A Report of the Kamaiya Conference, Kathmandu: INSEC, 1996, p. 17. 
fishery, cultural preservation, ethnic/cultural tourism development and awareness compaigns as well as other poverty alleviation measures. However, the other action plans proposed by Nepal Human Development ${ }^{62}$ can be included. The action plan is given below:

- Rehabilitation of the homeless and landless Kamaiya.

- Political and cultural campaign against bonded labour.

- Fixation of minimum wage and working hours.

- Creation of alternative employment opportunities.

- Development of agricultural forms and plantation for regular wage employment.

- Awareness building, literacy campaign and free formal education to school age children. ${ }^{63}$

The established relationship between the bonded labours and landlords has helped to keep balance on traditional agricultural system on one side and landless Kamaiya families has survived on the other. Overall, this study shows that the Kamaiya are partly exploited by the hill migrants and partly by the Tharu landlord themselves. Cederroth ${ }^{64}$ has also expressed that "For the landowners, the use of bonded labour power is a convenient way to secure a steady supply of labourers and to avoid problems during the peak seasons. Also for the labourers, the system has to advantage of giving an amount of long -term security, which is absent for ordinary day labourers who work for cash on short-term basis. On the other hand the system often amounts to conditions of virtual debt slavery and excessive exploitation. "Regarding the status and power, Rankin ${ }^{65}$ while discussing about the status and power of the Kamaiya, has distinguished from fixed status of African systems of slavery ${ }^{66}$ to a fluid "process" that accommodates the transition of former Kamaiya into Kisan communities. The Rana Tharu Kamaiya system is thus "open" in the sense employed by James Watson ${ }^{67}$ because Kamaiya are integrated into the kinship systems and societies of their masters ${ }^{68}$.

Some INGOs and NGOs have been actively empowering the Kamaiya as well. Literacy and awareness programmes as well as income generating schemes are being launched by those organizations. But simply empowering them in one

\footnotetext{
62. Nepal Human Development Report, f.n.no.59, p. 113.

63. Ibid.

64. Cederroth, f.n.no.44, p. 9.

65. Rankin, f.n.no.22.

66. Miers and Kopytoff, f.n.no.5.

67. Watson, f.n.no.9.
} 
small sector does not positively affect to the pan-Kamaiya of mid and far Western Nepal. From 1997 onward the landllords of Kanchanpur are gradually taking decision to give land to the Kamaiya under share cropping system. The land is owned by only one brother and his family. Remaining his other brothers can freely earn money from any other type of work. This is a kind of autogenous change which is taking place since 1997. In fact, indigenigational model is more better than the imported model. Sometimes, the imported model cannot keep balance between the two groups i.e. master and mastered. Only through indigenigational model the groups can go together for long time. If this change continues there will be no problem of developing unnecessary schemes.

\title{
Postscript
}

The emancipation of the Kamaiya by the middle of the year 2000 and a series of issues it brought forth has compelled the author to pen this postscript.The Kamaiya from frying pan to fire.

\author{
ægf v'bf XL Idnf gf ljzfn] ;gd \\ gf Ow/ s] /x] gf pw/ s] /x]/E
}

\section{pb'\{ pvfg (Urdu proverb)}

(Neither reached heaven nor received physical prosperity loss in both worlds.)

The next movement of Kamaiya started again and finally they were liberated. This post-emancipation part is based on the information published mainly in local magazines, Daily and Weekly Newspapers. On May 1, 2000, the 19 Kamaiya families of Shiva Raj Pant of Geta village of Kailali district did revolt against the Kamaiya system prevailing in Western Nepal. From May 1 to 16 July 2000, the bonded labours continuously struggled for their liberation with the direct and indirect assistance of certain political activists, social volunteers, and organization known as BASE. Nearly two-dozen NGOs-both local and international-had joined hands in the peaceful movement aimed at liberating the Kamaiya. By the same time Human Rightists and social volunteers were provoking to the Kamaiya on one side and the opposition political party CPN-UML had already registered the motion of stricture at both Lower and Upper Houses of the Parliament. Consequently, on 17 July 2000 that after five days long sit-in at

68. Rankin, f.n.no.22, p. 33. 
Bhadrakali, Kathmandu by more than 120 demonstrators for Kamaiya liberation, the government freed more than 85,000 bonded labours ${ }^{69}$. Some assumed the number to be about $200,000^{70}$ in the country's five Western districts.

While addressing to the Parliamentarians, Minister Siddha Raj Ojha said "From the day of 17 July 2000, the bonded labourers will not only be free of any obligations but they would not have to pay any money they owe to the landlords and are free from any bonds that are either written or verbal." Anyone who tries to force these bonded labourers to continue or those who are still involved in the practice will now be punished between three to ten years in prison ${ }^{71}$. Thus debt bondage is considered as illegal. This was immediately welcomed by CPN-UML and other few parliamentarians.

Dozens of jubiliant Kamaiya danced, sang and marched through the streets of the capital city before boarding buses bound to the Mid and Far-Western regions a day after the government outlawed the Kamaiya practice or bonded labour in the country ${ }^{72}$. About two thousand freed Kamaiya participated in a programme organised in Bardiya by the Kamaiya Liberation Movement Western Regional Committee to mark their victory day ${ }^{73}$.

Immediately the news coming from the Far Western Nepal painted a bleak picture for the just released Kamaiya. Angry landlords (jamindars) had driven many of their former Kamaiya out of their estates. Cases of physical and emotional torture including kidnapping of the Kamaiya were reported. Many Kamaiya with nowhere to go are turning up at the offices of BASE for relief. Against this backdrop voices were raised demanding that the government should exercise its moral responsibility to take care, at least for the next six months ${ }^{74}$.

According to Kamaiya Movement Mobilization Committee, which played a lead role in liberating the bonded labours, more and more former Kamaiya are fleeing from the homes of their landlords in the aftermath of the historic ban, ending in temporary sheds and tents set up by various (NGOs) in unsafe forest areas and along the river banks. The activists of the Committee put the number of homeless Kamaiya in and around Kailali and Kanchanpur districts at 2,525-plus ${ }^{75}$.

69. The Kathmandu Post, July 27, 2000.

70. Tiwari, f.n.no.34.

71. The Kathmandu Post, September 3, 2000.

72. The Kathmandu Post, July 18, 2000.

73. The Kathmandu Post, July 26, 2000.

74. Tiwari, f.n.no.34.

75. The Kathmandu Post, August 19, 2000. 
Following the government's announcement declaring the end of the Kamaiya system (of which bonded labour was a part), the power elite of Kathmandu have made two sets of commentaries. The first, coming from politicians (and certain big NGOs) consists of attempts at self-praise. The party in power, the Nepali Congress (NC) and the main opposition the Communist Party of Nepal Unified Marxist Leninist (UML) are both engaged in fabricating histories of their active involvement in liberating Kamaiya $^{76}$. Following the declaration, various statements were made regarding the issue, some called it historic, revolutionary and a very bold step towards attainment of social justice and called for economic measures that would free bonded labour from all debts and slavery practices imposed on them. Others discredited the declaration as mere propaganda, a type of land reform campaign, belated and unconvincing. To some political parties it was a step forward in facilitating socialism, to other it meant a distortion of the harmonious co-existence of jamindars and Kamaiya. Some viewed it as an important socio-economic measure, while some others viewed it as a pressure relief temporary pill not taking the issue in its proper perspective and totality ${ }^{77}$. Nowhere in these arrogant claims in acknowledgement of the fact that the government announcement came on the fifth day of a sit-in at Bhadrakali in downtown Kathmandu by more than 120 Kamaiya $^{78}$.

But the declaration came suddenly and unexpectedly. It came as an unplanned and ad hoc step without working out the necessary strategy and infrastructure. The forceful and bold tone of Declaration was soon softened and made mild to appeal to both the landlords and the Kamaiya to work in a conciliatory manner to the cultivation and reaping during the harvesting season ${ }^{79}$. The government did this because it realised its state of "Unpreparedness" for their rehabilitation ${ }^{80}$.

Article 20 of the 1990 Constitution concerns the right against exploitation. It states : "Traffic in human beings, slavery, serfdom or forced labour in any form is prohibited. Any contravention of this provision shall be punishable by law". If this is the provision that debtors slavery, then how can the government appeal to Kamaiya to go back and work for their former oppressors ? Does the government have the right to give such counselling, and that too only after a week of Kamaiya

76. Pratyush Onta, "Emergency relief for free Kamiya", Nepali Times, July 26, 2000.

77. Ram Bahadur K.C., "Kamaiya Emancipation: Propaganda or Reality", The Kathmandu Post, August 5, 2000.

78. Onta, f.n.no.76.

79. K.C., f.n.no. 77. 
emancipation ? Why did the government liberate them if it had no measure to offer for their resettlement or any economic activity that would enable Kamaiya to lead a life of dignity ? These are a few questions that the government must answer or be guilty of making it even worse for the former Kamaiya. It is no doubt true that with this suggestion the government has complicated the entire Kamaiya issue. ${ }^{81}$

They need land to cultivate, schools to educate their children and the right to express their views. The government cannot term them "agriculture labourers" and send them back to their previous masters, because then, all efforts to uplift the Kamaiya will come to nothing. ${ }^{82}$ A meeting of Central Monitoring and Coordination Committee formed to look into the problems of Kamaiya has decided to direct concerned District Development Committees (DDCs) to, among others, provide a kattha of land to every family of the displaced bonded labours. ${ }^{83}$

It is also believed that the jobless freed Kamaiya might create problems. In this regard the social scientists assume that "such situation in which the Kamaiya have been forced in at the moment might prompt a segment of the jobless youths to join the band of the Maoists' insurgents only to free this bowls". ${ }^{84}$ To recall, Maoists have in the recent weeks made an open call for young Nepalese youths to join their camp. Coincidentally the government too has invited applications from youths for recruitment to the police force. What a coincidence ?. ${ }^{85}$ If they do not join into both forces, they might go to India. If not so, the situation creates the social problem of crime, theft and prostitution. Kamaiya girls and women have been compelled to involve themselves in sex trade due to lack of employment opportunities as well as due to difficulties in coping with their liberated life in the absence of proper economic and rehabilitative packages for them. ${ }^{86}$ Fear has been increased in both sides of the Kamaiya and the landlords.

The question comes who won the game ? the Kamaiya ? the Nepali Congress ? the CPN- UML ? Human Rightists ? NGOs ? Historically, July 17 became the red letter day for the Kamaiya. From 17 to 20 July it was felt that the scenario turned into win-win for everybody. On the other side, the landlords became consolidated against the NGOs, Human Rightists, and government and

\footnotetext{
80. The Kathmandu Post, September 22, 2000.

81. The Kathmandu Post, July 27, 2000.

82. Ibid.

83. The Kathmandu Post, August 19, 2000.

84. The Telegraph, September 6, 2000.

85. Ibid.

86. The Kathmandu Post, September 22, 2000.
} 
they not only marched in the rally in the concerned districts but also they filed the case against the decision of government.

To see the worsening situation of Kamaiya all quarters have started blaming each other. Maximum comments, reactions, views and articles were published in different daily and weekly newspapers in the context of the Kamaiya emancipation and its effects. Most of the newspapers highlighted the movement of the Kamaiya, their emancipation, post-emancipation relief programme. Every one realised that the problem of Kamaiya is unsolved. In fact, the scenario was not win-win it is lose-lose for everybody. Who was behind the screen ? Who became the sufferer-the landlords ? the Kamaiya ? the human rightists ? the NGOs ? Who is responsible to bring such type of worsening conditions to the Kamaiya ? Is not this strange that the government has neither been able to resettle them nor has it come up with substantial measures for their rehabilitation. Is not this a silent tragedy ? Is not a play in the name of Kamaiya ? Now the Kamaiya are caught into cross-fire between the political parties. Now the Kamaiya are transformed from frying pan to fire. Does emancipation bring starvation ? Is emancipation meant to get a handfull of rice for survival ?

After the post -emancipation of Kamaiya, one NGO followed the case study of the ex-Kamaiya and summarizes that nearly half of the 200,000 ex-Kamaiya are under six years of age and 63 percent are less than eleven years old. Without shelter or sufficient food, they have no defense against diseases like malaria and encephalitis. Overwhelmed by recent catasthropies in India and Bangladesh, the regional relief agencies have been able to provide little to ease the sufferings of these desperate people. With winter approaching only an immediate will avert extensive loss of life. ${ }^{87}$

Till before the declaration of Kamaiya emancipation, at least there was relationship between the landlords and the Kamaiya. Now the relation has already been broken between them. Previously the Kamaiya life was centralized to the bukraha. Now they are confined to the plastic shade. Previously they were the kmaiya now they have become the squatters. Previously they were manipulated by the masters now they are manipulated by PONGOs (Political NGOs). While staying at bukraha the master was bound to listen the voice of the Kamaiya but now there is nobody to listen them. While staying with the landlords if the Kamaiya needed loan, the landlords without any hesitation used to provide loan. Now they cannot take loan from any institutions. Every day they are concerned

87. See Appendix. 
with food. They are having every day hand to mouth problem. The children had no problem of playing and loitering in and around bukraha before. While staying in the camp they are playing in slushy and wet and dirty and dusty places outside the neo-bukraha i.e. plastic shade. As far as the family structure is concerned, all individuals of Kamaiya family were free to play their role in their own space. Now it is very difficult to play the same given role inside the unimaginable limited space of plastic shade. One cannot maintain secrecy by any member of the family in that single space. The whole norms and values are changed. The above scenario reveals that Kamaiya as an institution has been totally deinstitutionalised and destrurctured. Previously the Kamaiya were dispersed but now they are made consolidated in camp to camp. The camp consolidation might the reconstructed heterogenous ethnicity. Before being Kamaiya they were the part of constructed ethnicity. Later on they were detached from their community and now they have become re-attached with their own community although they were from different distant villages. The landlords themselves felt unsecured and started to sell off their grains and movable properties at cheaper rate and deposited the cash in bank. They realised that it could be looted at any time. The harvesting season is at hand. They are trying to sell their crops right from the field. From next season onward they have decided to hire the labours from India paying IC. Rs 20/- per day including meal. If the labours come from India, will not be it a serious threat to the local employment in future ? Thus the problem is getting acute.

It is strange that the Kamaiya are emancipated only in five districts of Western Terai. The Kamaiya and Kamlhari of Kathmandu are not freed from debt bondage. There are not less than 3,000 Kamaiya and kamlhari who are employed under the same Kamaiya system that was prevailed in Western Terai. Regarding them, the political parties like Nepali Congress, CPN-UML, NGO's and medias have neither raised the voice nor carried news for their emancipation. Most of the landlords, politicians and bureaucrats who have come to Kathmandu from those of five districts and neighbouring northern districts have employed the Tharu Kamaiya and Kamlhari in Kathmandu based residences. There are also many Kamaiya employed by the landlords in Butwal and Bhairahawa. Should not they be emancipated ? Even if they are free, are they really ready to leave their masters ?

The question comes what about the Rana Tharu Kamaiya ? There are several Rana Tharu Kamaiya in Kailali and Kanchanpur districts. The local and regional reporters carried the news only about the Dangaura Tharu Kamaiya and their involvement in Kamaiya liberation movement. Even after the emancipation, only the Dangaura Tharu Kamaiya are highlighted by the news media. The 
question comes whether the Rana Tharus joined their hands with the Dangaura Kamaiya or not. If they did not join, why? Are not they affected from populist and abrupt decision? Conclusively it can be said that all the actors, except Maoists (quoted in some Nepali Daily and Weekly Newspapers), are losing their faith from the both landlords and Kamaiya. Those Kamaiya who were involved in the liberation movement, and remaining others who left their landlords have now shown great repentance of losing the landlords, food and shelters. Therefore, this is no more than lose - lose game of all quarters. In fact, the unilinear decision taken by government created maximum problems in the Kamaiya areas. If the government had followed multi-linear approach of emancipation, there would have only little problem in the mentioned areas. It is yet to be seen what happens in future?

\section{Appendix*}

Description of Kamaiya Families

District : Kailali

\begin{tabular}{|l|l|l|l|l|l|}
\hline $\begin{array}{l}\text { No. of total } \\
\text { families }\end{array}$ & $\begin{array}{l}\text { No. of total } \\
\text { members }\end{array}$ & $\begin{array}{l}\text { From 0-5 years } \\
\text { old }\end{array}$ & $\begin{array}{l}\text { From 5-10 years } \\
\text { old }\end{array}$ & $\begin{array}{l}\text { From 10-14 } \\
\text { years old }\end{array}$ & $\begin{array}{l}\text { From 14 to } \\
\text { above }\end{array}$ \\
\hline 1562 & 10787 & $\mathrm{M}=2267$ & $\mathrm{M}=1132$ & $\mathrm{M}=573$ & $\mathrm{M}=1472$ \\
& $\begin{array}{l}\mathrm{F}=2295 \\
\text { Total = 4562 }\end{array}$ & $\begin{array}{l}\mathrm{F}=1123 \\
\text { Total =2255 }\end{array}$ & $\begin{array}{l}\mathrm{F}=499 \\
\text { Total = 1072 }\end{array}$ & $\begin{array}{l}\mathrm{F}=1426 \\
\text { Total = 2898 }\end{array}$ \\
\hline
\end{tabular}

District : Kanchanpur

\begin{tabular}{|l|l|l|l|l|l|}
\hline $\begin{array}{l}\text { No. of total } \\
\text { families }\end{array}$ & $\begin{array}{l}\text { No. of total } \\
\text { members }\end{array}$ & $\begin{array}{l}\text { From 0-5 years } \\
\text { old }\end{array}$ & $\begin{array}{l}\text { From 5-10 years } \\
\text { old }\end{array}$ & $\begin{array}{l}\text { From 10-14 } \\
\text { years old }\end{array}$ & $\begin{array}{l}\text { From 14 to } \\
\text { above }\end{array}$ \\
\hline 800 & \multirow{M}{M}{$=841$} & $\mathrm{M}=481$ & $\mathrm{M}=228$ & $\mathrm{M}=497$ \\
& 4126 & $\begin{array}{l}\mathrm{F}=853 \\
\text { Total = }=4694\end{array}$ & $\begin{array}{l}\mathrm{F}=486 \\
\text { Total = 967 }\end{array}$ & $\begin{array}{l}\mathrm{F}=205 \\
\text { Total = 433 }\end{array}$ & $\begin{array}{l}\mathrm{F}=535 \\
\text { Total = 1032 }\end{array}$ \\
\hline
\end{tabular}

Kamaiyas who are in $\mathbf{2 4}$ camps in Kailali and Kanchanpur district

\begin{tabular}{|l|l|l|l|l|l|}
\hline $\begin{array}{l}\text { No. of total } \\
\text { families }\end{array}$ & $\begin{array}{l}\text { No. of total } \\
\text { members }\end{array}$ & $\begin{array}{l}\text { From 0-5 years } \\
\text { old }\end{array}$ & $\begin{array}{l}\text { From 5-10 years } \\
\text { old }\end{array}$ & $\begin{array}{l}\text { From 10-14 } \\
\text { years old }\end{array}$ & $\begin{array}{l}\text { From 14 to } \\
\text { above }\end{array}$ \\
\hline \multirow{2}{*}{1000} & $\mathrm{M}=1745$ & $\mathrm{M}=617$ & $\mathrm{M}=335$ & $\mathrm{M}=905$ \\
& 7152 & $\begin{array}{l}\mathrm{F}=1765 \\
\text { Total }=3510\end{array}$ & $\begin{array}{l}\mathrm{F}=628 \\
\text { Total }=1245\end{array}$ & $\begin{array}{l}\mathrm{F}=270 \\
\text { Total }=605\end{array}$ & $\begin{array}{l}\mathrm{F}=887 \\
\text { Total }=1792\end{array}$ \\
\hline
\end{tabular}

* Source : Karuna Singh B.C. 